\title{
TERRITÓRIO DA MINERAÇÃO: UMA CONTRIBUIÇÃO TEÓRICA
}

\author{
Haruf Salmen Espindola, Natália Moreira Ferreira, lesmy Elisa Gomes Mifarreg
}

Universidade Vale do Rio Doce

\begin{abstract}
Resumo
O território da mineração no Brasil ganhou destaque com o desastre de 5 de novembro de 2015, desencadeado pelo rompimento da barragem da Samarco Mineração, na bacia do Rio Doce. Os eventos fizeram emergir a existência do complexo minero-metalúrgico e os riscos, principalmente para populações mais frágeis (comunidades rurais negras e mestiças, indígenas, ribeirinhos pobres, agricultores e pescadores). $\mathrm{O}$ artigo examina a questão pelo conceito de envirotechnical, de Sara Pritchard, historiadora ambiental. A definição de espaço geográfico proposta por Milton Santos foi ampliada pela introdução dos conceitos de biocultura, território e multiterritorialidade. A combinação dos conceitos possibilitou considerar as heterogeneidades socioespaciais e ecossistêmicas, de modo a fazer emergir o cerne do fenômeno criado pela presença do complexo minerador: as contradições como relacionalidades marcadas pelo poder.
\end{abstract}

Palavras chave: Mineração, Rio Doce, Envirotechnical, Biocultura, Relações de Poder.

\begin{abstract}
The mining territory in Brazil was highlighted by the disaster of November 5, 2015, triggered by the rupture of the Samarco Mineração dam in the Rio Doce basin. The events have made apparent of the miningmetallurgical complex and the risks represented by them, especially for the most fragile populations (black and mestizo rural communities, indigenous, poor riverine, farmers and fishermen). The article examines the issue by the concept of envirotechnical by Sara Pritchard, environmental historian. The geographic definition of space proposed by Milton Santos was amplified by the introduction of the concepts of bioculture, territory and multiterritoriality. The combination of concepts made it possible to consider socio-spatial and ecosystem heterogeneities, in order to make emerge the core of the phenomenon created by the presence of the mining complex: contradictions as relations marked by power.
\end{abstract}

Key words: Mining; Rio Doce; Envirotechnical; Bioculture, Power relations.

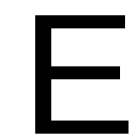

ste trabalho tem por objetivo oferecer uma contribuição teórica para se analisar criticamente o que se denomina de "território da mineração". A motivação surgiu do desastre da Samarco/Vale/BHP, desencadeado pelo rompimento da barragem de rejeito de Fundão, em 5 de novembro de 2015, cujos impactos negativos atingiram a Bacia Hidrográfica do Rio Doce, nos estados brasileiros de Minas Gerais e Espírito Santo. A necessidade de compreender o território da mineração conduziu a busca de conceitos que fossem ferramentas analíticas que se prestassem ao exame crítico, considerando as relações de poder presentes em todos eventos relacionados. Com essa contribuição teórica se busca fugir dos relatos descritos e juízos de valores que se multiplicaram depois dos eventos de 5 de novembro.

Tomou-se como escala a bacia hidrográfica (ARRUDA, 2015) e, consequentemente, uma parte significativa do território da mineração em Minas Gerais ficou de fora. Isso se justifica porque a questão de fundo é o rompimento de barragens de rejeitos de mineração e, caso isso ocorra, os sedimentos liberados seguiriam a rede de drenagem até a calha do rio principal, terminando no 
mar. A escolha da bacia do rio Doce foi determinada pelo desastre da Samarco/Vale/BHP. A delimitação também foi necessária porque se pretendia verificar a distribuição espacial do complexo minero-metalúrgico que foi o objeto motivador dessa reflexão teórica.

O termo complexo minero-metalúrgico foi entendido como um conjunto de sistemas de objetos indissociáveis do conjunto de sistemas de ações (SANTOS, 1996), englobando mineração e siderurgia. Isso porque os dois setores são imbricados e, a partir da crise mundial de 2008 , cresceu a tendência de verticalização. ${ }^{1}$ Para especificar o setor de mineração se usou complexo minerário. A análise da problemática relacional do território da mineração e das questões desencadeadas pelo desastre tiveram como premissa que as relacionalidades são, em todos níveis e esferas, marcadas pelo poder.

Antes do desastre, a existência de um território da mineração, em Minas Gerais, ficava restrita aos agentes relacionados ao mercado de minério; aos investidores em ações; aos atores governamentais, engenheiros e técnicos também vinculados à atividade minerária; aos trabalhadores diretos e indiretos das empresas; aos acadêmicos de áreas de conhecimento correlacionadas à mineração ou que tenham interesse no assunto; e às populações residentes nas áreas onde se localizam as instalações do complexo minero-metalúrgico (cidades, vilas, povoados e comunidades rurais). Com o desastre se processou a passagem do especializado ao generalizado, ou seja, o território da mineração emerge como uma realidade na consciência da população em geral.

Para as diferentes populações da bacia do rio Doce isso se deu de uma forma direta; para o restante de Minas Gerais e Espírito Santo, indiretamente; e para o Brasil e o resto do mundo, foi um acontecimento repercutido negativamente pela opinião pública, inclusive desencadeando protestos e atos performáticos (manifestantes sujos de lama, encenação de morte, videoclipes de cantores e artistas famosos, entre outros). Os protestos ocorreram na bacia do rio Doce e em diferentes lugares do Brasil e do Mundo, ampliando a reverberação na mídia nacional e internacional. Nesse sentido, o desastre fez emergir a existência do complexo minero-metalúrgico operado por diferentes empresas, de forma isolada, em sociedade ou por joint venture.

Pode-se falar em emergência porque o território da mineração, construído e consolidado na segunda metade do século $X X$, não se apresentava de forma objetiva à consciência da população, como um real capaz de afetar efetivamente a vida pessoal, familiar e comunitária, além de ameaçar a natureza. Para as populações da bacia do rio Doce, que se encontram a jusante do complexo minerário, foi somente depois do 5 de novembro de 2015 que isso se tornou realidade, no sentido de ser mais que o estar informado ou ter conhecimento, mas como percepção da existência das "coisas" e/ou das "ações" que podem afetar de forma danosa a existência de todos. Assim, o que de fato emergiu foi o risco (SANTOS, 2016a, p. 193), trazendo um novo tempo, marcado pela incerteza frente ao presente e ao futuro.

\footnotetext{
${ }^{1}$ A verticalização mineração-siderurgia se intensificou depois da crise mundial de 2008. "A luta mundial para garantir o suprimento de matérias-primas de alto custo está criando uma nova dinâmica na indústria do aço: produtores estão se tornando fornecedores e fornecedores estão se tornando produtores". Instituto Aço Brasil. Brasil é foco em nova onda de verticalização da siderurgia. Publicado em 02/09/2008. Disponível em http://www.acobrasil.org.br/site2015/noticia_interna.asp?id=5071. Acessado em 26 de fevereiro de 2018.
} 
Antes não se conhecia o risco, inclusive, nos anos recentes, a Samarco Mineração S.A. foi várias vezes homenageada, sendo eleita a melhor empresa mineradora do ano de $2007 .{ }^{2}$ O relatório anual de 2014 expressou logo no início a sua "responsabilidade ambiental": "Uso responsável dos recursos naturais, projetos de eficiência e novas tecnologias são os mecanismos que aplicamos para reduzir nossos impactos ambientais". ${ }^{3}$ O desastre trouxe o risco: probabilidade de perigo e ameaça física para as pessoas, comunidades, empresas e para o ambiente. O sentimento de medo, objetivo ou imaginado, de algo que é visto como poderoso demais para prejudicar a todos. Isso não significa, no entanto, que exista um efetivo conhecimento por parte da população sobre a localização, estrutura e funcionamento do complexo minerário.

Antes do desastre, na região, a atividade minerária estava associada à companhia Vale (antiga Companhia Vale do Rio Doce), às minas de Itabira, à figura do ferroviário, à Estrada de Ferro Vitória a Minas e ao porto de Tubarão, sendo que a única associação com o risco se referia aos cruzamentos com os trilhos da ferrovia. Em 5 de novembro de 2015 o desastre revelou o risco da atividade minerária, ao se produzir o acontecimento, no sentido dado por Pierre Nora (1976), imagens vistas por milhões de pessoas, reiteradamente, ao ser veiculado por todos os meios de comunicação, particularmente pelas redes de televisão. Isso tudo multiplicado muitas vezes graças à Internet e aos smartphones. O público tomou conhecimento de outras grandes companhias de mineração além da Vale S.A. e diferentes sistemas técnicos, particularmente sobre a Samarco e o transporte tubular (mineroduto). Portanto, o desastre se converteu em acontecimento nacional e internacional, não apenas pelas mãos das mídias comerciais e alternativas, mas também pela ação de instituições de ensino fundamental e médio. ${ }^{4}$

Como foi dito no início, as questões levantadas pelo desastre motivaram a busca por conceitos que possibilitem compreender criticamente os impactos relacionados aos grandes projetos de investimento de capital, particularmente ao que se denomina território da mineração.

\section{O Território da Mineração como um Envirotechnical Landscape}

O que denominamos de complexo minero-metalúrgico é o conjunto de sistemas de objetos indissociáveis do conjunto de sistemas de ações formado pelas minas (extração do minério, beneficiamento, alocação dos rejeitos e embarque); pelo transporte ferroviário ou tubular; pelas usinas de pelotização (produção das pequenas esferas de ferro usadas na fabricação do aço); pelos portos (embarque e entrega no destino); pelas siderúrgicas (que operam suas próprias minas) e mineradoras (que operam suas próprias siderúrgicas); pelas hidroelétricas (operadas pelas siderúrgicas ou mineradoras); pelos laboratórios de pesquisa e desenvolvimento; pelas instalações que servem aos diferentes departamentos técnicos operacionais e de manutenção; pela infraestrutura que atende aos setores de intermediação (suprimentos, abastecimento, segurança etc.); pelos prédios escritórios que abrigam os diferentes departamentos administrativos, diretorias, gerências

\footnotetext{
2 Publicado na revista Indústria da Mineração - Edição Especial, Ano II, no 10, set. de 2007, p. 14. Disponível em http://www.ibram.org.br/sites/700/784/00000896.pdf. Acessado em 26 de fevereiro de 2018.

3 Samarco. Relatório Anual de Sustentabilidade 2014. Disponível em http://relatoweb.com.br/samarco/2014c/meioambiente-e-ecoeficiencia.html. Acessado em 26 de fevereiro de 2018.

${ }^{4}$ Um exemplo é o Colégio Recanto do Rio de Janeiro, que produziu um excelente material sobre o desastre em sua página na Internet, didaticamente ilustrada. Cf. Desastre em mariana. Disponível emhttps://www.colegiorecanto.com/artigo/artigodefault/view/id/421/titulo/desastre_em_mariana. Acessado em 17 out. 2017.
} 
diversas e a governança central; pelos escritórios no exterior, entre outras instalações, infraestruturas, equipamentos. O complexo depende da ação de milhares de homens e mulheres vinculados às empresas; às terceirizadas e aos fornecedores e prestadoras de serviços. Tudo funciona de forma hierárquica, conforme cada instância e competências.

Esse complexo minero-metalúrgico compõe uma paisagem híbrida presente no espaço, não de forma contígua nem excludente, mas concentradas em pontos do espaço interligados por infraestrutura de transporte, comunicação e redes de dados. No conjunto forma sistemas de objetos e sistemas de ações (SANTOS, 1996) sobrepostas e contidas na paisagem geral múltipla, que se formou por diferentes temporalidades e heterogêneos processos de produção do espaço. $O$ complexo minero-metalúrgico forma um sistema territorial, como conceituado por Raffestin (1993, p. 150), por constituir-se "sistemas de tessituras, de nós e de redes organizadas hierarquicamente" para cumprir finalidades determinadas, asseguradas por mecanismos de "controle sobre aquilo que pode ser distribuído, alocado e/ou possuído". É um sistema territorial porque realiza de forma integrada uma ordem e coesão espacial que se denomina de território. Afirmar a existência de um território da mineração é reconhecer que tais "sistemas constituem invólucro no qual se originam as relações de poder" necessárias à manutenção das estruturas, formas e função. O sistema territorial cria, ao mesmo tempo, vizinhanças, acessos e convergências; por outro lado, promove disjunções, rupturas e distanciamentos. O sistema territorial "segrega sua própria territorialidade, que os indivíduos e as sociedades vivem" (RAFFESTIN, 1993, p. 161).

O sistema territorial, mesmo que dinâmico e sujeito às mudanças, é produção espacial elaborada/realizada (fixos e fluxos que podem ser analisados). Ao território corresponde uma territorialidade, que the é própria, nos termos definido por David Sack (1986): capacidade de afetar, influenciar ou controlar pessoas, coisas, fenômenos e relações, através da delimitação e da afirmação do controle sobre uma área geográfica, que assim se converte em território. Não apenas a construção, mas a continuidade do sistema territorial requer emprego permanente de energia e informação. Esse conceito se aplica ao complexo minero-metalúrgico e, por isso, esse pode ser definido como um território da mineração, onde natureza e cultura estão interligadas pela técnica/tecnologia.

O resultado da instalação e funcionamento do sistema territorial é a produção de uma paisagem híbrida que pode ser definida pelo conceito de envirotechnical landscape proposto por Sara Pritchard (2011). Tal conceito foi utilizado por Simonini (2017) no estudo do sistema portuário na região Nordeste do Brasil. Pritchard se refere aos "ambientes modificados, produzidos e gerenciados", ou seja, uma paisagem híbrida, no qual tecnologia, natureza e território estão imbricados e inter-relacionados. Essa paisagem híbrida nasce da convergência (confluência) do humano e não humano, do tecnológico e do ecológico, da técnica e da norma.

O território da mineração, em Minas Gerais e Espírito Santo, se constituiu no século XX, com os grandes investimentos de capital na mineração, siderurgia, hidroelétricas e infraestrutura. No caso do complexo minerário, as barragens de rejeitos ocupam um lugar de destaque nessa envirotechnical landscape (Figura 01). Não é possível dissociar os sistemas técnicos minerários, as barragens de rejeitos, as formas do relevo e a rede de drenagem ou rede hidrográfica. Na bacia do rio Doce o relevo com intensas variações de forma e altitude resultou das diferentes intensidades da rede hidrográfica, que ora se adaptaram a estrutura ora se impuseram a ela (COELHO, 2017). O traçado do rio Doce é um exemplo dessa relação tensa das forças que confi- 
guraram o relevo e a rede de drenagem. Seu curso se assemelha ao desenho do litoral Capixaba (ES), no sentido Sul-Norte, porém muda bruscamente, a partir da cidade de Governador Valadares, para o sentido Oeste-Leste, até atingir sua foz no distrito de Regência, município de Linhares, ES. As características geomorfológicas da bacia hidrográfica permitem dividi-la em três unidades bem distintas: Alto, Médio e Baixo Rio Doce.

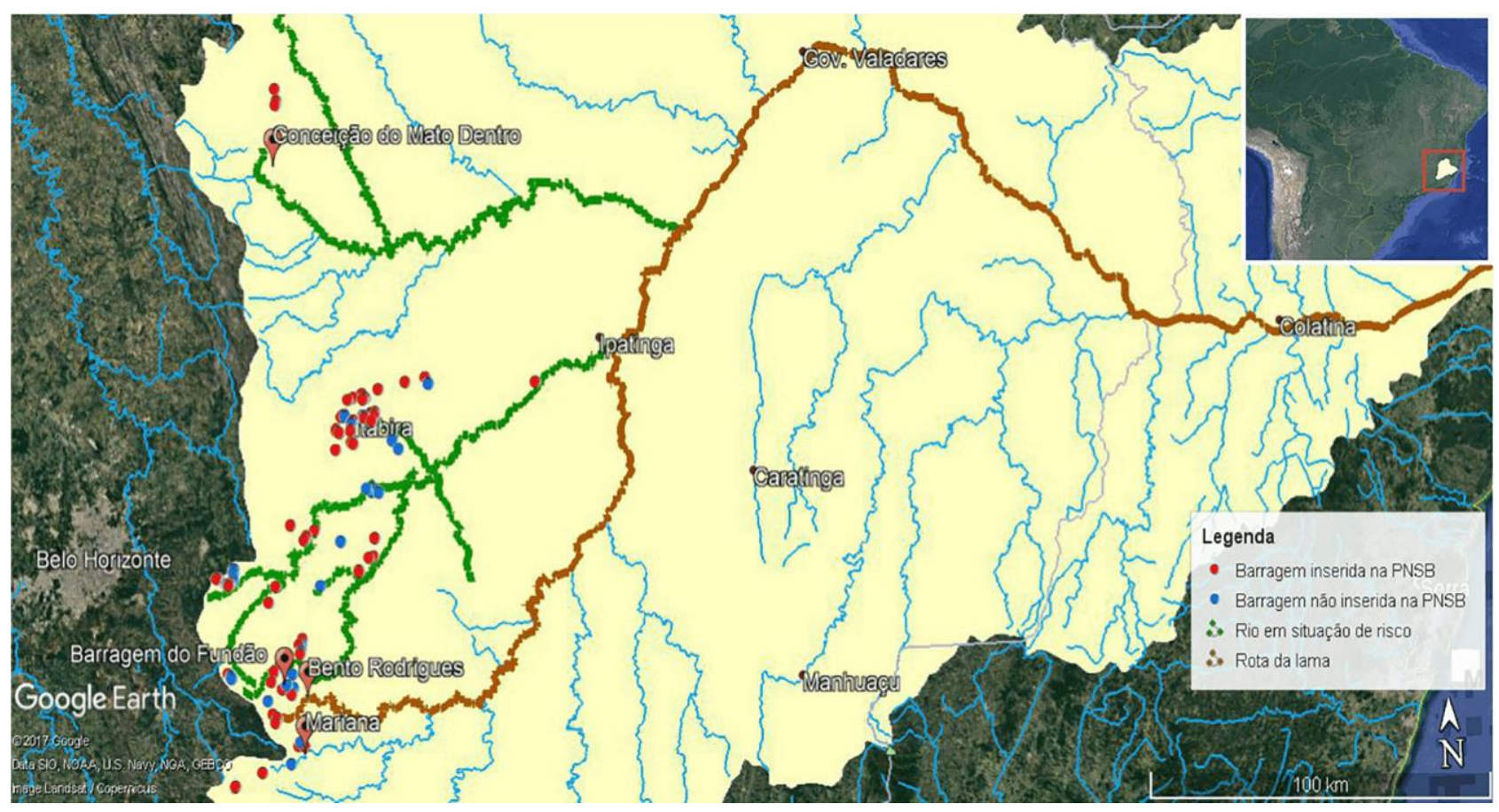

Figura 1. Imagem do Google Earth. A imagem foi produzida ao se adicionar ao Google Earth os dados do Cadastro Nacional de Barragens de Mineração do Departamento Nacional de Produção Mineral (DNPM, 2016a), órgão do Ministério de Minas e Energia do Governo do Brasil, referentes às barragens inseridas na Política Nacional de Segurança de Barragens (pontos vermelhos) e barragens não inseridas (pontos azuis). Em seguida se recortou a área correspondente ao Alto e Médio rio Doce, com o intuito de incluir as barragens localizadas nas cabeceiras dos grandes afluentes do rio Doce: no canto esquerdo inferior da figura (Ouro Preto e Antônio Pereira) estão as barragens da bacia do rio do Carmo (ver figura 02); acima de Antônio Pereira até Santa Maria de Itabira, as barragens da bacia do rio Piracicaba; no canto esquerdo superior (Conceição do Mato Dentro) estão as barragens da bacia do rio Santo Antônio.

A unidade Alto Rio Doce compreende uma altitude de $2.600 \mathrm{~m}$, cujo limite é a confluência do rio Piracicaba com o Doce. São diversos formadores, com suas nascentes nas serras da Mantiqueira e Espinhaço. O rio recebe o nome de Doce a partir da confluência com o rio do Carmo. É no Alto Rio Doce que estão localizadas as barragens e diques de contenção de sedimentos de mineração, particularmente nas cabeceiras dos principais afluentes da margem esquerda (rios do Carmo, Piracicaba, Santo Antônio, Corrente, Suaçuí Pequeno e Suaçuí Grande). ${ }^{5}$ Estas barragens se situam na encosta leste da Serra do Espinhaço, dentro do Quadrilátero Ferrífero. Portanto, trata-se de uma envirotechnical landscape que contém em si mesma a eventualidade do rom-

\footnotetext{
${ }^{5}$ A unidade Médio Rio Doce, cujas altitudes podem variar de 76 m (Aimorés) a 780 m (Peçanha), mas com elevações predominantes entre 200 e 500 metros, se estende da foz do rio Piracicaba até a desembocadura do rio Manhuaçu, na divisa dos estados de Minas Gerais e Espírito Santo. Já a unidade Baixo Rio Doce está totalmente inserida no estado do Espírito Santo e possui altitudes inferiores a $245 \mathrm{~m}$, que decrescem gradualmente em direção ao litoral, até a média de $22 \mathrm{~m}$ da planície costeira quaternária.
} 
pimento de barragens e que, consequentemente, pela disposição das mesmas, pela topografia e rede de drenagem, haveria o deslocamento dos sedimentos até o rio Doce.

No caso de concretização do risco presente na envirotechnical landscape formada pelo complexo minerário se produzirão eventos negativos em sequência, em função da própria configuração do relevo, rede hidrográfica e rio Doce. A concretização do risco é o desastre causado pelo deslocamento dos sedimentos contidos nas barragens. No caso da ocorrência de sinistro, o relevo, rede hidrográfica e rio Doce atuarão para aumentar as proporções de dano ao ambiente e à população à jusante dos empreendimentos, bem como conduzirão os danos até o mar. Foi o que aconteceu com rompimento da barragem de Fundão da Samarco Mineração S.A., quando houve o derramamento de mais de 40 milhões de $\mathrm{m}^{3}$ de sentimentos, que devastou as áreas à jusante da barragem e, no trajeto pelo rio Doce, produziu diferentes impactos sobre a população, meios de produção, núcleos urbanos e ecossistemas, incluindo os efeitos negativos para o mar do litoral do Espírito Santo e Bahia.

\section{Atividade minerária em Minas Gerais como um envirotechnical system}

No Brasil o aproveitamento dos "recursos minerais" é disciplinado pelo Código de Mineração (Decreto Lei $n^{\circ} 227$, de 28 de fevereiro de 1967), que define no seu segundo artigo "os regimes de aproveitamento das substâncias minerais". No primeiro inciso do Art. $3^{\circ}$ define o que são os recursos minerais: "massas individualizadas de substâncias minerais ou fósseis, encontradas na superfície ou no interior da terra". Entretanto, se aceitarmos as ponderações de Raffestin (1993, p. 223), de que a "matéria (ou substância), encontrando-se na superfície da terra ou acessível a partir dela, é assimilável a um "dado"', podemos reler o que está proposto na definição do Código de Mineração. O sentido de afirmar que a matéria é um dado significa que essa é simplesmente o resultado de "forças que agiram ao longo da história da terra sem nenhuma participação ou intervenção do homem", ou seja, preexiste a toda ação humana. Nesse sentido a matéria (orgânica ou inorgânica) é a natureza, que em sua qualidade de matéria é uma realidade tangível, porém não é o objeto do aproveitamento humano. O objeto da apropriação (pelo valor de uso ou valor de troca) são as propriedades presentes em diferentes elementos que compõem a matéria, pela possibilidade dessas se ligarem ou entrarem em relação com o uso humano: como produto e/ou meio de produção.

A relação, a rigor, não é com a natureza, mas com determinadas propriedades que são integradas a uma prática. O processo relacional que converte a natureza em recurso equivale ao mesmo processo que converte o espaço em território. Não apenas a população, mas o recurso também é categoria fundamental na definição do conceito de território. O processo relacional ao converter a natureza em recurso dá origem a uma segunda natureza (uma realidade socioambiental territorial). Não se trata de um processo universal e muito menos inerente à natureza, mas de um processo espacial e historicamente determinado, marcado por relações de poder. Portanto, a rigor, não existiriam "recursos naturais, só matérias naturais": "é uma concepção histórica da relação com a matéria que cria a natureza sociopolítica e socioeconômica dos recursos" (RAFFESTIN, 1993, p. 225). 
Essa relação somente é possível pela mediação da técnica, que é um subconjunto da territorialidade (saber e saber fazer), enquanto mediadora das relações que o homem, enquanto grupo, pode ter com as propriedades das matérias. Conforme Raffestin (1993, p. 227): "A tecnicidade pode se definir como o conjunto das relações que o homem, enquanto membro de um grupo, mantém com as matérias às quais pode ter acesso. A tecnicidade, em relação à matéria, é o apêndice da territorialidade, é até mesmo um subconjunto da territorialidade". A matéria permaneceria na sua condição de matéria natural (natureza) na ausência da intervenção externa. Essa intervenção é espacial e historicamente condicionada à territorialidade: técnica (capacidade de manipular suas propriedades), social (demanda pelas propriedades identificadas), econômica (capacidade de transportar, transformar em produto e fazer circular para o consumo) ou políticojurídica (capacidade de possuir a coisa e controlar o acesso a suas fontes).

Considerando a análise de Raffestin (1993, p. 223-228) sobre as relações entre recurso e território, particularmente sobre a relação entre natureza, recurso e técnica, propomos um diálogo epistemológico com o conceito de envirotechnical, proposto por Sara Pritchard (2011). Segundo a autora, esse conceito constituiria uma ferramenta analítica para o exame da confluência entre natureza, tecnologia, Estado-Nação e suas relações, historicamente dadas, ou seja, a não separação da dimensão humana (cultura) da natureza (biótico e abiótico). Pritchard (2011, p. 77) afirma que a França não foi a única que criou narrativas em torno da tecnologia em larga escala, durante o século XX, mas destaca que: "a transformação pós-guerra do Ródano ${ }^{6}$ exemplifica a construção mútua da tecnologia e da cultura, bem como a centralidade da natureza e da tecnologia para a construção da identidade nacional e do Estado-Nação".

O conceito de envirotechnical pode ser trabalhado em conjunto com os conceitos de território (recurso) e territorialidade (técnica), auxiliando-se mutualmente. A combinação desses conceitos permitiria evitar que o complexo minerário fosse reduzido à sua condição de "aproveitamento das substâncias minerais", ou seja, aos sistemas de objetos e infraestruturas criados pela atividade humana, por meio da mediação da técnica, para extrair da natureza e transportar de determinada localidade recursos de valor para o mercado, destinado ao consumo interno e/ou exportação. O complexo minerário é um território, compõe uma territorialidade e se constitui como um envirotechnical system, ao entrelaçar espacial e historicamente múltiplos sistemas humanos e não-humanos, particularmente sistemas tecnológicos, sistemas ecológicos e sistemas normativos. O conceito de envirotechnical system comporta a articulação operativa de artefatos, práticas, normas, instituições, pessoas e ecologias. Conforme Pritchard ${ }^{7}$ (2011, p. 19):

Minha segunda ferramenta analítica é o conceito de envirotechnical system. Eu defino este termo como a configuração historicamente e culturalmente específica de sistemas 'ecológicos' e 'tecnológicos' entrelaçados, que podem ser compostos de artefatos, práticas, pessoas, instituições e ecologias. Eu escolhi 'enviro' (forma abreviada para 'environment') no lugar de 'eco' (de 'ecossistema') por dois motivos. 'Environment' tem um sentido mais amplo, não se limitando aos de recursos 'naturais'. Como sugere este ponto, uso o ambiente para enfatizar que as sociedades humanas moldam a grande maioria dos ecossistemas, direta ou indiretamente. Isso é certamente verdade, como tem sido para a maior parte da história humana. Para os propósitos deste estudo, o meio ambiente do rio Ródano é constituído pelo rio e é uma bacia hidrográfica, mas se estende além desses limites

\footnotetext{
${ }^{6}$ O rio Ródano tem $812 \mathrm{~km}$ de extensão. Ele nasce na Suíça (231 km) e flui pelo sudoeste da França (581 km), até desaguar no Mediterrâneo.

7 Tradução livre.
} 
quando as decisões e ações são externas ao sistema hidráulico do rio, que não afetaram ou foram afetadas por ele. O uso do termo 'technical' (abreviatura para 'technological') segue os recentes estudos sociais e históricos sobre a tecnologia, que postula uma definição abrangente: conhecimento, habilidades e ferramentas de marketing ou ação - uma definição mais alinhada ao pensamento francês, que combina conhecimento técnico, práticas e objetos, do que à noção de tecnologia anglo-americana, centrada em artefatos.

Com base nos conceitos propostos até aqui, pode-se afirmar que as dez maiores corporações do setor de minério de ferro brasileiro, concentradas no Estado de Minas Gerais, além das que estão no setor de alumínio, manganês, nióbio e ouro, formam os diversos envirotechnical system minerários do estado (DNPM, 2016b). Entre as unidades federativas do Brasil, Minas Gerais ocupa o primeiro lugar na produção de minério, respondendo por $53 \%$ da produção brasileira de minerais metálicos e $29 \%$ de minérios em geral. O minério de ferro ocupa o imaginário popular, mas o estado possui reservas de nióbio para mais de 400 anos, num quadro em que são apenas três minas em todo o mundo; detém a maior reserva de manganês; e, além desses, na lista dos principais minérios produzidos constam bauxita, ouro, paládio, prata, dolomito, filito, quartzo, calcário, chumbo, zinco, fosfato, feldspato, granito, zircônio, cobalto, enxofre, níquel, barita. A atividade mineradora está distribuída por 250 municípios de Minas Gerais, totalizando mais de 300 minas em operação, com $67 \%$ das minas classe A (mais de 3 milhões t/ano). O estado ocupa o primeiro lugar como produtor de minério de ferro, ouro, zinco, fosfato e nióbio (esse com $92 \%$ da produção mundial); o segundo como produtor de bauxita; e o terceiro como produtor de níquel.

O minério de ferro ocupou o primeiro lugar entre os produtos exportados pelo Brasil no último trimestre de $2015 .{ }^{8}$ As reservas de minério de ferro estão distribuídas nas seguintes proporções entre os estados brasileiros: Minas Gerais (72,5\% das reservas), Mato Grosso do Sul $(13,1 \%)$ e Pará $(10,7 \%) .{ }^{9}$ O minério exportado originou-se, principalmente, dos estados de Minas Gerais (51,6\%) e Pará (32\%). ${ }^{10}$ Por empresa o mercado de exportação ficou distribuído da seguinte forma: Vale S.A e Coligadas com 89,4\%; Samarco Mineração S.A. com 7,9\%; e Anglo American com 2,7\% das exportações. ${ }^{11}$ No mercado de aço, o estado mineiro continua sendo o maior produtor brasileiro, com $32,7 \%$ de participação. ${ }^{12}$

Minas Gerais tem sete municípios listados entre os dez maiores produtores de minério brasileiro, sendo que o município de Itabira, na bacia do rio Doce ${ }^{13}$, é o maior produtor do Brasil. ${ }^{14}$

\footnotetext{
${ }^{8}$ Fonte: ADVFN Brasil: Portal de investimentos em ações da bolsa de valores do Brasil, com cotações da Bovespa e BM\&F. Disponível em http://br.advfn.com/jornal/2016/01/exportacao-minerio-de-ferro-foi-pelo-terceiro-mes-consecutivofoi-o-principal-produto-exportado-pelo-brasil-em-dezembro-de-2015. Acessado em 20 nov. 2017.

${ }^{9}$ DNPM. Sumário Mineral - 2015. Brasília, n. 35, 2016. Disponível em http://www.dnpm.gov.br/dnpm/sumarios/sumariomineral-2015. Acessado em 20. nov. 2017

10 Informações sobre a economia mineral brasileira - 2015. Instituto Brasileiro de Mineração - IBRAM. P.. 23. Disponível em http://www.ibram.org.br/sites/1300/1382/00005836.pdf. Acessado em 20 nov. 2017.

11 DEPEC - Departamento de Pesquisas e Estudos Econômicos/Bradesco. Minério de Ferro - junho de 2017. Disponível em https://www.economiaemdia.com.br/EconomiaEmDia/pdf/infset_minerio_de_ferro.pdf. Acessado em 20 nov. 2017.

12 Análise do Mercado do Aço - 2016. SICETEL Sindicato Nacional da Indústria de Trefilação e Laminação de Metais Ferrosos. Disponível em http://sicetel.org.br/antigo/sicetel2014/wp-content/uploads/2015/13/anuario-sicetel-2016.pdf. Acessado em 20 nov. 2017.

${ }^{13}$ Conforme dados da Agência Nacional de Águas (ANA), a Bacia Hidrográfica do Rio Doce está localizada na região sudeste do Brasil e possui aproximadamente $83.500 \mathrm{~km}^{2}$ de extensão, sendo que $86 \%$ dessa extensão pertencem ao estado de Minas Gerais (MG) e 14\% ao Espírito Santo (ES). Nos dois estados a bacia do rio Doce abriga uma população residente de cerca de 3,5 milhões de habitantes, distribuída em 222 municípios. Disponível em http://www2.ana.gov.br/paginas/servicos/planejamento/planoderecursos/baciariodoce.aspx. Acessado em 17 out. 2017.
} 
Dos 41 municípios mineiros produtores de ferro, 21 deles se encontram na bacia do rio Doce, estando a maioria concentrada na sub-bacia do rio Piracicaba (dez municípios), seguindo os municípios da bacia do rio Santo Antônio (cinco), do rio do Carmo (dois), do rio Suaçuí Grande (dois), do rio Corrente (um) e do rio Suaçuí Pequeno (um). ${ }^{15}$

A Samarco Mineração S.A, uma joint-venture entre as duas grandes mineradoras globais (Vale S.A. e a anglo-australiana BHP Billiton), mantinha uma barragem de água (Santarém) e duas barragens de rejeitos da mineração (Germano e Fundão) na sua unidade de Germano, no município de Mariana, distrito Santa Rita Durão, localizadas acima do povoado de Bento Rodrigues, onde existiam 200 casas e residiam 620 habitantes. Os eventos relacionados ao rompimento da barragem de Fundão tiveram início por volta das $15 \mathrm{~h} 30$ do dia 5 de novembro de 2015. A onda de lama de rejeito, depois de destruir os povoados de Bento Rodrigues, Paracatu de Baixo e Gesteira, se deslocou pelo rio do Carmo até a calha do rio Doce, chegando ao mar no dia 22 de novembro de 2015.

O desastre trouxe para o centro da discussão a questão das barragens de mineração, localizadas nas cabeceiras de três importantes afluentes da margem esquerda do rio Doce, como pode ser visto na figura 01. Os detalhes da área próxima ao complexo de Germano da minerado Samarco podem ser observados na Figura 2. Em destaque aparecem as minas pertencentes à Samarco e Vale S.A., a barragem de Germano e demais barragens, deixando claro o risco direto para o povoado de Bento Rodrigues (risco consumado) e para Santa Rita Durão (distrito de Mariana) e Antônio Pereira (distrito de Ouro Preto). A Imagem do Google Earth mostra o conjunto de sistemas de objetos localizados no divisor das bacias dos rios do Carmo e Piracicaba, respectivamente as minas de Timbopeba da Vale S.A. e de Germano da Samarco; e as minas Alegria e Fábrica Nova da Vale S.A. Em ambos os casos, qualquer desastre nas barragens atingiria a calha do rio Doce.

\footnotetext{
14 IBRAM. Informações sobre a Economia Mineral do Estado de Minas Gerais - 2014. Brasília: Instituto Brasileiro de Mineração - IBRAM, 2014. Disponível em http://www.ibram.org.br/sites/1300/1382/00004355.pdf. Acessado em 20 nov. 2017.

15 Instituto Brasileiro de Mineração - IBAM. Panorama da Mineração em Minas Gerais. Brasília: IBRAM/ SINFERBASE Sindicato Nacional da Indústria da Extração do Ferro de Metais, $2015 . \quad$ Disponível em http://www.ibram.org.br/sites/1300/1382/00006212.pdf. Acessado em 20 nov. 2017.
} 


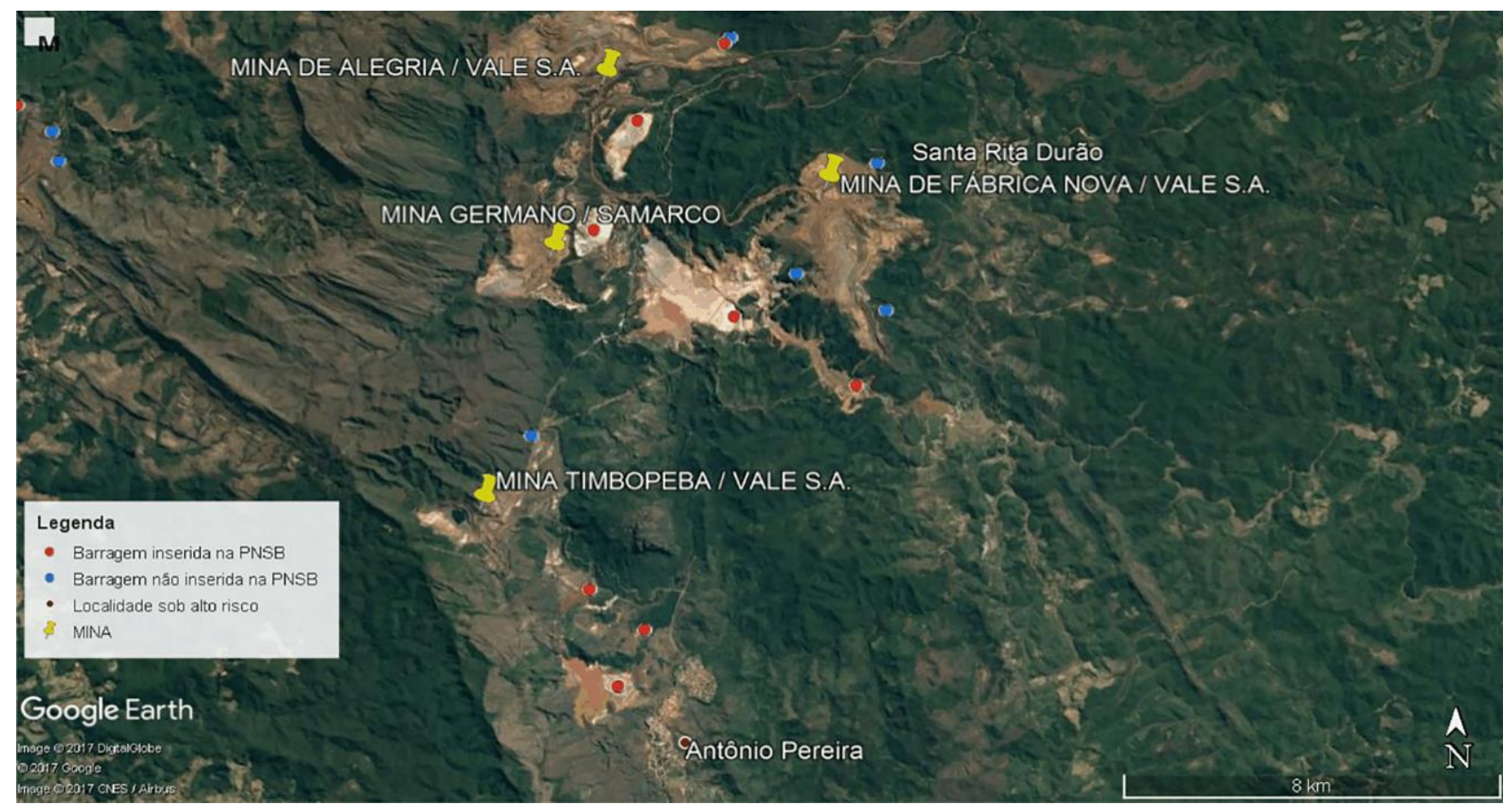

Figura 2: Imagem do Google Earth: acima se vê a mina da Samarco Mineração S.A., com destaque para a barragem de Germano. Logo a baixo fica o povoado de Bento Rodrigues, localizado no trajeto da enxurrada de lama que desceu do rompimento da barragem de Fundão, que ficava à direita da barragem de Germano, localizando-se a jusante as duas a barragem de Santarém. Na esquerda, mas abaixo fica outro complexo minerário e os barramentos, tendo a jusante o distrito de Antônio Pereira (assinalado), município de Ouro Preto.

\section{Os engenheiros e o envirotechnical system}

O envirotechnical system minerário, que configura o território da mineração, é o resultado final de processos marcados por relações de poder em diferentes esferas: políticas, econômicas, sociais, culturais e técnicas. As relações de poder (conflitos, negociações, acordos ou imposições administrativas ou judiciais) na produção e manutenção do envirotechnical system compõem o que Pritchard (2011, p. 23) define como envirotechnical regime.

A minha terceira e última ferramenta baseia-se no conceito de envirotechnical system, mas concentra-se nas relações sociais e nas estruturas de poder por trás do seu desenvolvimento, produção e operação. Aqui proponho a ideia de envirotechnical regime: instituições, pessoas, ideologias, tecnologias e paisagens que, em conjunto, definem, justificam, constroem e mantêm um envirotechnical system específico como norma [sistema regulado]. Se a noção de envirotechnical system é em grande parte descritiva - isto é, descreve as características particulares dos sistemas ecológicos e tecnológicos incorporados -, então, os envirotechnical regime são a formulação prescritiva, instrumental e o uso desses sistemas por grupos ou instituições para fins específicos. O plural novamente enfatiza que múltiplos regimes são possíveis dentro e ao longo de períodos e culturas diferentes.

Os engenheiros são agentes chaves no interior do envirotechnical regime, pelo reconhecimento que possuem como especialistas autorizados: detentores do saber e da técnica/tecnologia capazes de dar forma, fazer funcionar e manter um envirotechnical system. São eles que devem responder diariamente aos desafios de diferentes terrenos, apresentar as alterativas de construção, elaborar os planos, definir os materiais, técnicas e tecnologias cabíveis, se responsabilizando 
tecnicamente pelos resultados finais. Pritchard (2011, p. 25), referindo-se à França, destaca o papel das agências estatais e engenheiros na realização dos objetivos de implantação dos envirotechnical system que fizeram do rio Ródano uma envirotechnical landscape, com suas hidrelétricas, usinas nucleares, agricultura moderna, navegação, além de terem feito da França uma potência nuclear. Todos esses envirotechnical system dependeram de os engenheiros remodelarem os recursos "ecológicos" do rio Ródano. Esse processo não foi simples, pois havia "pouco consenso sobre o que significava o desenvolvimento do pós-guerra, mesmo para os funcionários estatais, os burocratas governamentais envolvidos com a agricultura, desenvolvimento econômico, energia hidroelétricas, navegação e energia nuclear".

Simonini (2017, p. 112), ao tratar da produção do envirotechnical system portuário das cidades de Fortaleza, Natal e Paraíba (1869-1934), no Nordeste brasileiro, demonstra o papel crucial dos engenheiros no interior do envirotechnical regime, não apenas pela função especificamente profissional, mas também pela capacidade de se articularem em diferentes esferas de governo, do nível municipal ao federal, e no interior da sociedade civil, particularmente junto as organizações representativas do empresariado local; além de se apresentarem e serem vistos como agindo no interesse do "progresso". Simonini destaca o papel representado pela formação recebida nas escolas de engenharia, centradas em moldar engenheiros com competência técnica e, ao mesmo tempo, capazes de lidar com problemas operacionais imprevistos, conforme os diferentes meios físico-geográficos. ${ }^{16}$

Nas últimas três décadas do século XIX e nas primeiras do século seguinte, os engenheiros "usaram o conhecimento técnico e a ampla divulgação científica como artifícios legitimadores de sua posição, construindo o imaginário de Cruzados do Progresso" (SIMONINI, 2017, p. 160). Essa posição se fortaleceu ainda mais, a partir da Era Vargas (1930-1945), com o início do processo de modernização e industrialização brasileira. Entre o Estado Novo (1937-1945) e o Regime Militar (1964-1985) os engenheiros assumiram posição central na elaboração dos planos de infraestrutura, da intervenção econômica do Estado e da direção dos grandes projetos de investimento de capital, tais como Companhia Siderúrgica Nacional (1940), a Companhia Vale do Rio Doce (1942), a Fábrica Nacional de Motores (1943), a Hidrelétrica do Vale do São Francisco (1945); Rodovia Federal BR 116 com 4.513 Km (1936-1951), Petrobras (1953); Usinas Siderúrgicas de Minas Gerais S.A (1956); Central Hidrelétrica Furnas (1957), Construção de Brasília (1956-1960), Eletrobrás (1962), Nuclebrás (1974), entre outras.

Os engenheiros ocupam um lugar central no debate sobre os rumos do desenvolvimento brasileiro e na direção de grandes empreendimentos. Esse é o caso do engenheiro e empresário Roberto Simonsen, protagonista central do debate que ficou conhecido como controvérsia brasileira sobre o desenvolvimento, no qual deixa claro a sua defesa da industrialização. Ele chegou a propor a planificação global da economia, o que conduziria ao aprofundamento da intervenção estatal, com o objetivo de fomentar o desenvolvimento capitalista (ESPINDOLA, 1988). O Estado cumpriu um papel crucial, segundo Triner (2011, p. 45-46), quando solucionou os problemas de financiamento e organização do setor minerário e da indústria de base. "A formação da Vale [Companhia Vale do Rio Doce - CVRD], como empresa estatal de mineração baseou-se em uma

\footnotetext{
${ }^{16}$ Simonini (2017, p. 111-164) dedica muito espaço a discussão da formação dos engenheiros e as estruturas dos currículos, que apresentava um núcleo comum para as diversas áreas da engenharia e, ao mesmo tempo, previa uma formação técnica específica.
} 
solução estatista para duas longas controvérsias: a industrialização e o domínio dos recursos minerais". ${ }^{17}$ A mineração e siderurgia produziram "externalidades benéficas" que favoreceram a industrialização brasileira e impactaram a região onde operavam.

Marta Zorzal Silva (2004) evidencia os impactos da implantação e crescimento da Vale sobre a região do Vale do Rio Doce, no contexto da industrialização brasileira por substituição de importações, ocorrida após a Segunda Guerra Mundial. Esclarece a estratégia da companhia para crescer e diversificar, por meio de associações e constituição de Joint Venture. A presença da Vale, pela infraestrutura criada funcionou como atrativo para outros grandes investimentos de capital na mineração, siderurgia e celulose. Para a autora, os impactos dessa estratégia modificaram e redefiniram o perfil socioeconômico da região do Vale do Rio Doce, nos estados de Minas e do Espírito Santo. Mais que o perfil socioeconômico, se opera a configuração espacial de um território da mineração a partir do envirotechnical landscape formado pelo complexo minero-metalúrgico.

Nesse e em outros setores econômicos os engenheiros ocuparam papel central. Campos (2012), na sua tese sobre a vinculação entre a indústria da construção pesada e o regime militar, fornece um amplo panorama sobre essa posição central ocupada pelos engenheiros no processo de industrialização, particularmente para a expansão da infraestrutura de transporte, comunicação, aeroportos, siderurgia, mineração e energia. "A formação universitária principal do avanço científico associado à industrialização, às novas técnicas e tecnologias foi a Engenharia" (Campos, 2012, p. 36).

No setor minerário o protagonismo dos engenheiros se manifesta plenamente em todas as dimensões: técnicas, econômicas, administrativas e políticas. O marco dessa presença é representado pela Companhia Vale do Rio Doce (Vale S.A.), criada em 1942 e privatizada em 1997. Nesse período, a presidência da companhia foi ocupada por 14 engenheiros (49 anos), dois economistas (5 anos) e um militar (um ano). Fischer (1914) examina o papel da elite técnica e científica brasileira no período dos Governos de Getúlio Vargas, particularmente estuda a Companhia Vale do Rio Doce. Para o autor esse e outros empreendimentos podem ser vistos como campo privilegiado da atuação dos engenheiros, que podem assim demonstrar sua contribuição para o progresso do país. O autor examina detalhadamente os anos das duas primeiras presidências da Vale: Israel Pinheiro ${ }^{18}$ (1942-1945) e Dermeval Pimenta ${ }^{19}$ (1946-1951).

\footnotetext{
17 Getúlio Vargas criou a Vale, a partir da incorporação da Companhia Brasileira de Mineração e Siderurgia S.A e Itabira de Mineração S.A. (Decreto-Lei $n^{\circ} 4.352$, de $1^{\circ}$ de junho de 1942), empreendimentos comandados por Percival Farquhar. Pelo Art. $6^{\circ}$ do referido decreto-lei a finalidade da nova companhia era a "exploração, comércio, transporte e exportação do minério de ferro das minas de Itabira, e exploração do tráfego da Estrada de Ferro Vitória-Minas...". Também se atribuía uma outra finalidade para a Vale, conforme o parágrafo $7^{\circ}$ : distribuir no máximo $15 \%$ dos lucros líquidos como dividendo e "o que restar dos lucros líquidos constituirá um fundo de melhoramentos e desenvolvimento do Vale do Rio Doce", acrescentando que os recursos deveriam ser investidos em projetos que fossem elaborados pelos estados de Minas Gerais e Espírito Santo. Portanto, no projeto da Vale se incluía dupla tarefa: a primeira era cria a empresa de mineração e, a segunda, era promover o desenvolvimento do Vale do Rio Doce.

${ }_{18}$ Natural de Caeté, estado de Minas Gerais, Israel Pinheiro se graduou pela Escola de Minas de Ouro Preto, em 1919, onde recebeu formação ampla nas engenharias de Minas, Metalurgia e Civil; tendo se destacado como o melhor aluno, ganhou bolsa para se especializar em siderurgia na Europa. Entrou para a vida pública em 1922 (26 anos), como vereador e agente executivo - o prefeito da época - da sua cidade natal. Antes de assumir a presidência da Vale, foi Secretaria da Agricultura, Viação e Obras Públicas do estado de Minas Gerais (1933-1935). Depois que deixou a Vale se destacou ainda por ter dirigido as obras de construção de Brasília (1956-1960); e pela eleição para o Governo de Minas Gerais (966-1971).

19 Natural de São João Evangelista, estado de Minas Gerais, Dermeval Pimenta se graduou pela Escola de Minas de Ouro Preto, em 1918, como engenheiro de Minas e Civil. Entrou para a vida pública em 1927 (34 anos), como prefeito de sua cidade natal. Depois ocupou diversos cargos públicos ou cargos em empresas estatais, antes da presidência da
} 
Em 1944, a Vale começava a sair do papel, ainda no contexto da Segunda Guerra Mundial, com a chegada dos equipamentos prometidos pelos EUA. O contexto enfrentado por Israel Pinheiro e seus engenheiros foi o pior possível: ferrovia inadequada, infraestrutura que não existia; equipamentos que não chegavam; pessoal insuficiente; falta de dinheiro para saldar empréstimos e, até mesmo, para pagar os empregados, fornecedores, inclusive pequenos varejistas. Um outro fator limitador era a interferência direta de diretores americanos, em função do apoio do governo dos EUA e dos empréstimos do Eximbank. O envolvimento dos americanos no Vale do Rio Doce se estendeu a diferentes áreas: implantação da Vale S.A.; reforma da Estrada de Ferro Vitória a Minas para transporte de minério em grande escala; erradicação da malária e de outras endemias; saneamento e implantação do sistema urbanos de abastecimento de água e de esgoto; e implantação da exploração e exportação de minério de mica. Esse envolvimento colocava os engenheiros e técnicos brasileiros sob tutela de engenheiros americanos, relativizando o comando brasileiro sobre os programas e projetos em implantação (VILARINO, 2015).

Resolver essa situação de ingerência foi uma das prioridades da gestão do mineiro Dermeval Pimenta, tendo ele conseguido passar o controle da companhia para as mãos dos engenheiros nacionais (PIMENTA, 1950). O jornal "A Noite", de 29 de abril de 1946, noticiava a palestra de Pimenta no Rotary Club de Belo Horizonte, com uma manchete espetacular: "Mais do que o Vale das maravilhas, o Vale do Rio Doce será o Vale da redenção da economia brasileira". ${ }^{20} \mathrm{~A}$ situação da empresa começou a melhorar em 1947, quando as exportações quadruplicaram (175 mil contra 40 mil toneladas no ano anterior); cresceram os investimentos de capital do governo federal e se obteve novo empréstimo do Eximbank. Essa injeção de capital permitiu reiniciar as obras de mecanização das minas e de reconstrução da Estrada de Ferro Vitória a Minas. ${ }^{21}$ Em 1948 as exportações mais que dobraram e, nesse ano, se fez a primeira reestruturação administrativa e, três anos depois Demerval Pimenta deixava a presidência (1951) tendo "terminado o trabalho de implantação definitiva".

Em 1968 o Banco de Desenvolvimento Econômico de Minas Gerais - BDMG publicou o Diagnóstico da Economia Mineira, onde se encontra uma avaliação do setor minerário.

[...] Minas Gerais apareça, sempre, como polo primordial na produção de minério de ferro no cenário brasileiro. O setor de extração de minério de ferro auferia, quando da produção do Diagnóstico, crescimento médio de 14,2\% ao ano, possibilitando a expansão em larga escala da exportação do produto. Sendo que, de acordo com o documento, 99\% do minério produzido no Brasil era então oriundo de Minas Gerais, levando à conclusão de que o destacável crescimento produtivo e surto exportador de minério de ferro eram frutos do bom desempenho de tal setor em Minas Gerais. (Diagnóstico, 1968, vol. V: $48-49$ e 55). (GODOY et al., 2010, p. 378)

No regime militar brasileiro, no contexto de concentração econômica e favorecimento dos grandes projetos de investimentos de capital, a Vale ocupou, junto com a Petrobras, papel rele-

\footnotetext{
Vale. Depois de deixar a Vale esteve à frente de diversos empreendimentos, com destaque para a siderúrgica Usiminas, que ajudou a fundar; a siderúrgica Acesita (atual Aperam South América), onde ficou na presidência até 1964; Companhia Mineira de Alumínios (Alcominas), como diretor até 1968, entre outros.

20 Jornal A Noite 29 de abr 1946. Mais do que o Vale das Maravilhas, O Vale do Rio Doce será o Vale da Redenção da Economia Brasileira. Disponível em http://memoria.bn.br/DocReader/Hotpage/HotpageBN.aspx?bib=348970_04\&pagfis=39634\&url=http://memoria.bn.br/do creader\#. Acessado em 20 nov. 2017.

${ }^{21}$ FGV/CPDOC. Verbete Dermeval Jose Pimenta. Disponível em http://www.fgv.br/cpdoc/acervo/dicionarios/verbetebiografico/dermeval-jose-pimenta. Acessado em 7 nov. 2017.
} 
vante para a consolidação da industrialização brasileira. Entretanto, a transformação da mineração brasileira em um empreendimento global se deu antes do Golpe Militar de 1964: foi obra de outro mineiro, o engenheiro Eliezer Batista da Silva, como presidente da Vale (1961-1964) e, ao mesmo período, como Ministro das Minas e Energia (1962-1963). Em 1968 ele retorna a uma posição de destaque na companhia, ao assumir a presidência da Rio Doce Internacional S/A, subsidiária da Vale com sede em Bruxelas. No período de 1972 a 1977, quando Minas Gerais apresentou índice de crescimento econômico superior a 10\% a.a., atingindo até 19,4\% a.a., em 1974 (FERNANDES, 2007, p. 16), Eliezer Batista atuou como consultor e promotor de negócios para o governo mineiro, atraindo indústrias de bens de capital para o estado. ${ }^{22}$ No final do regime militar, assumiu novamente a presidência da Vale (1979 a 1986), sendo responsável pela implantação do Projeto Grande Carajás e pela expansão global da companhia.

Portanto, os engenheiros ocuparam uma posição crucial no processo de modernização e industrialização do Brasil. No que se refere particularmente a criação do envirotechnical system da mineração na bacia do Rio Doce, essa presença é indiscutível, pela posição de comando que tiveram na direção dos empreendimentos e, ao mesmo tempo, pela capacidade de articulação político-social por ocuparem posições chaves no aparelho de Estado e na sociedade. A importância da Vale foi ressaltada por diversos estudos (SILVA, 2004; TRINER, 2011; FISCHER, 2014; ESPINDOLA, 2015). Entretanto, não menos importante que a competência técnica e o protagonismo dos engenheiros é a discussão ética da responsabilidade dos engenheiros como principais formadores do envirotechnical landscape. Se essa questão se restringia ao problema da ética profissional regulada pelos conselhos federal e regionais da categoria, a partir do desastre da Samarco/Vale/BHP, faz-se necessário ampliar a análise para agregar aos conceitos de território, territorialidade e envirotechnical uma nova abordagem da ética que se denomina de biocultural (ROZZI, 2013). Essa ferramenta analítica possibilita incluir outros agentes, os seres, outras territorialidades e outras relações que não as diretamente acopladas ao envirotechnical system.

Se abre, dessa forma, o conceito de multiterritorialidade (HAESBAERT, 2007) para que se inclua na dimensão da territorialidade humana a diversidade de seres e, principalmente, para considerar o conceito de coabitação, ou seja, outros seres são coabitantes com os quais os seres humanos co-constituem suas identidades e suas territorialidades. A ética biocultural e a multiterritorialidade comporiam uma ferramenta analítica eficiente para discutir as contradições e os riscos no envirotechnical system da mineração, particularmente o desastre da Samarco/Vale/BHP, trazendo a existência e explicitando os múltiplos interesses, as relações de poder e os atores coenvolvidos, particularmente, aqueles mais vulneráveis.

\section{Território da Mineração: vulnerabilidade e poder}

O cenário econômico para 2030, dos setores de mineração e siderurgia, traçado pelo poder público e pela iniciativa privada, conduziria a uma expressiva expansão do território da mineração. As exportações correspondem a $40 \%$ da produção siderúrgica nacional, mas o Estado e as corpora-

22 Verbete ELIEZER BATISTA DA SILVA. Disponível em http://www.fgv.br/cpdoc/acervo/dicionarios/verbetebiografico/eliezer-batista-da-silva. Acessado em 7 nov. 2017. 
ções esperam a ampliação dessa participação internacional. Conforme o Instituto Aço do Brasil, o projeto é elevar a posição do Brasil no mercado mundial e, para isso, se teria que cumprir as metas de aumento da produção e exportações de minérios e produtos siderúrgicos. Essas metas seriam garantidas com a ampliação das plantas industriais e infraestruturas existentes e, ao mesmo tempo, com a entrada em funcionamento de novos projetos em desenvolvimento, inclusive no setor siderúrgico, muitos deles voltados essencialmente à exportação. ${ }^{23}$

Desde 2013 estão em andamento mudanças nos marcos legais, particularmente as propostas de alteração do decreto-lei n 227, de 28 de fevereiro de 1967 (Código de Mineração), que levariam à expansão do território da mineração. Dentre as propostas, estão a flexibilização dos licenciamentos, desregulamentação e outras medidas que procuram criar condições para novos investimentos e instalação de grandes projetos minerários e siderúrgicos. Na esfera estadual, a Assembleia Legislativa do Estado de Minas Gerais (ALMG), apesar de transcorridos apenas 20 dias do início do desastre da Samarco/Vale/BHP e dos acontecimentos estarem se reverberando na mídia nacional e internacional, não se intimidou em aprovar, em turno único, projeto de lei que flexibiliza o licenciamento ambiental para mineradoras (25/11/2015) - proposta do executivo de número 2.946/2015.

Entretanto, as práticas discursivas conciliadoras mobilizadas pelas empresas e governos perderam força e abriu-se um cenário marcado por contradições, tensões e conflitos. O cenário foi influenciado pelas repercussões nacional e internacional do desastre; pelas pressões sociais e políticas dos movimentos dos atingidos, particularmente, pela ressonância das ações do povo Krenak, de ampla visibilidade. Nesse quadro, destacaram-se as mobilizações em diversos países, promovidas por organizações sociais, instituições civis, celebridades e atores políticos. O Ministério Público Federal, de Minas Gerais e do Espirito Santo mantém papel ativo e protagonista na questão do desastre.

A ALMG respondeu a esse cenário com o Projeto de Lei - PL no 3.676/2016, que busca aumentar o controle sobre o licenciamento ambiental e a rigidez da fiscalização de barragens no estado. Entretanto o Ministério Público de Minas Gerais (MPMG) apresentou aos deputados diversas críticas ao projeto de lei: não prevê a licenciamento trifásico; ${ }^{24}$ nem exige audiências públicas em todas as comunidades atingidas; falta a obrigação da caução (garantias financeiras prévias); e não determina o uso de tecnologias mais seguras e menos impactantes. A proposta alternativa encaminhada pelo MPMG é denominada de projeto de lei de iniciativa popular "Mar de Lama Nunca Mais" (PL 3.695/16) e está tramitando anexa ao PL 3.676/16.

Quaisquer mudanças no Código de Mineração, se aprovadas, afetarão os territórios usados por populações tradicionais e/ou ocupados por Unidades de Conservação. O ordenamento do território econômico encontra suporte no território normado, ou seja, é marcado por relações de poder e dependem da correlação das forças sociais e políticas que determinam a produção nor-

\footnotetext{
23 Instituto Brasileiro de Siderurgia - IBS. Siderurgia Brasileira: Princípios e Políticas. Disponível em http://www.acobrasil.org.br/site/portugues/biblioteca/Livro_Policy_final_2.pdf. Acessado em 22 nov. 2017.

${ }^{24}$ Licenciamento trifásico é o conjunto de três licenças distintas, dadās em etapas sucessivas: Licença Prévia; Licença de Instalação; e Licenças de Operação. Isso implica distintas fases de análise: viabilidade quanto à concepção e localização; viabilidade de instalação conforme os planos, programas e projetos aprovados; finalmente, a licença de operação, após verificar o cumprimento do que consta nas duas licenças anteriores, bem como os instrumentos de controle ambiental e as condicionantes para a operação ou desativação, se necessário.
} 
mativa soberana do Estado. As discussões na Câmara dos Deputados sobre o marco legal da atividade minerária expressam essas relações, conforme Magno (2015, p. 93-94):

\begin{abstract}
A partir da análise dos dados referentes à economia mineral brasileira, o governo começou a dar mais atenção ao setor, o que refletiu num aumento de propostas de planos e projetos de leis encaminhados ao Congresso Nacional a fim de modificar o Código da Mineração no país, para expandir essa atividade. O Plano Nacional da Mineração 2030 (PNM) é um desses documentos.
\end{abstract}

O PNM, publicado pela SGM/MME ${ }^{25}$, desenhou o cenário em médio prazo para a mineração no Brasil e, com uma perspectiva essencialmente setorial, ele objetivou identificar as principais limitações que enfrentava a indústria mineral, bem como delinear políticas para superá-las. Como resultado, o PNM estabeleceu uma rota para a expansão da mineração no país. Tomando o ano de 2008 como base para este processo, o PNM prevê o aumento da extração de níquel em 400\%, de cobre em $360 \%$, de ouro em $260 \%$, de ferro em $210 \%$ e de bauxita em $195 \%$ até o ano de 2030.

Como se tratou no início, o complexo minero-metalúrgico moldou uma organização espacial particular que se denominou de território da mineração. É preciso, no entanto, destacar que esse território expressa uma determinada territorialidade (econômica, social, jurídico-política, técnica e ecológica) e um ordenamento espacial (sistema de objetivos e sistema de ações). Entendese por ordenamento a produção do território normado e do território como norma, ou seja, por um lado tem-se o ordenamento jurídico promovido pelo poder soberano do Estado; por outro tem-se o ordenamento criado pelas estruturas, formas e funções dos sistemas de objetivos e sistemas de ação (ANTAS JR., 2005), que podemos identificar com o conceito de envirotechnical system de Pritchard (2011).

É preciso considerar o papel central desempenhado pelo Estado na "luta pelo uso do espaço", por meio da norma. Como poder soberano, o Estado promove a regulação das relações sociais no território e as relações com o território. O ordenamento espacial/territorial se não for capaz de suprimir as tensões, pelo menos promove o enquadramento e delimita o campo operacional dos atores, para que as tensões não desemboquem em conflitos abertos. A regulação do Estado transforma o espaço em território normado, no sentido sintetizado por Ricardo Antas Jr. (2005, p. 136): "normas jurídicas mantêm intensa relação com a produção e a configuração do território.". Portanto, é preciso ter claro, ao se considerar o conceito de envirotechnical regime, que o Estado está no centro das lutas no interior da envirotechnical landscape pela apropriação das matérias naturais, localização dos empreendimentos, operação das atividades minerarias, comercialização etc., tendo em vista que são processos dependentes da regulação estatal. O desastre da Samarco/Vale/BHP deixou clara a necessidade de se considerar os fatores estatais que contribuem para a vulnerabilidade do envirotechnical system da mineração, tais como regulamentação, licenciamento e fiscalização. ${ }^{26}$

A territorialidade da mineração, no entanto, não cobre toda a área da bacia hidrográfica nem se constitui como exclusiva e excludente. Aqui caberia o conceito de territorialidade proposto

\footnotetext{
${ }^{25}$ Secretaria de Geologia, Mineração e Transformação Mineral (SGM)/Ministério de Minas e Energia (MME).

${ }^{26} \mathrm{O}$ inquérito policial conduzido pela Superintendência Regional de Polícia Federal/Minas Gerais (IPL n. ${ }^{\circ}$ 1843/2015 SRPF/MG ) apontou situações que permitem nomear diversos problemas: regulamentação precária, fiscalização omissa e multas irrisórias; equipamentos e pessoal insuficientes para desempenho das funções de fiscalização e monitoramento; pressões diversas sobre os agentes públicos na função fiscalizadora; agenciamentos para acelerar os processos de tramitação e aprovação dos licenciamentos.
} 
por Raffestin (1993, 158-59): “multidimensionalidade do 'vivido' territorial pelos membros de uma coletividade, pelas sociedades em geral. Os homens 'vivem', ao mesmo tempo, o processo territorial e o produto territorial por intermédio de um sistema de relações existenciais ou produtivas...". Para o autor, todas essas relações, em qualquer nível, são marcadas pelo poder, à medida que os atores "procuram modificar tanto as relações com a natureza como as relações sociais". No processo relacional, os atores também se automodificam.

O envirotechnical landscape, na verdade, é o que Deleuze e Guattari (2010, p. 259) denomina de sobrecodificação das multiplicidades e disciplinamento dos corpos, no sentido de criar uma ordem e unicidade territorial. Todavia, é sempre uma tentativa, que espacial e historicamente, pode se realizar com maior ou menor intensidade (ou até mesmo se desfazer pelo processo de secessão, que segundo David Sack é uma das propriedades que define a territorialidade): não ocorre de fato a supressão da "multidimensionalidade do vivido territorial" ou das multiplicidades, segundo os dois autores. Se a sobrecodificação fosse total ocorreria a supressão e desaparecimento das segmentações - particularidades e/ou singularidades preexistentes ou nova, que podem se constituir ao longo do tempo. As multiplicidades subsistem "mais ou menos modificadas, mais ou menos arranjadas". O que é suprimido, ao fim das contas, é a característica determinante da condição "pré-capitalista" da segmentação, ou seja, de prevalecer a tendência à diferenciação e heterogeneidade de territórios. "A sobrecodificação é precisamente a operação que constitui a essência do Estado, que mede ao mesmo tempo sua continuidade e sua ruptura com as antigas formações" (DELEUZE; GUATTARI, 2010, p. 264).

O território da mineração, na verdade, está sobreposto a diferentes territórios usados, com diferenciação dependendo da área da bacia hidrográfica. Em alguns pontos está sobreposto de forma completa, mas em outras de forma muito tênue (até mesmo subterrânea, como é o caso do transporte por dutos e tubulações). Se observarmos a bacia hidrográfica, tomada como escala espacial, e se pudéssemos ter uma radiografia completa, ver-se-ia múltiplas territorialidades sobrepostas ou justapostas, que teriam se constituído ao longo do processo histórico de sua ocupação.

Aqui podemos retornar as propostas de mudanças no Código de Mineração e às metas do Plano Nacional da Mineração - 2030, cujos objetivos visam fortalecer e ampliar a capacidade do envirotechnical system minerário e siderúrgico, para chegar à conclusão de que isso resultaria na sua maior capacidade de conformar o espaço, dando-lhe a forma de sua própria lógica e, consequentemente, ampliando seu papel de produtor de norma. A confluência entre o ordenamento territorial promovido pelo Estado e o ordenamento promovido pelo envirotechnical system localizado espacialmente em determinados pontos, em última instância, é determinada pela lógica global do mercado. Isso é o que Santos (1996, p. 338) denomina de Mundo, ou seja, o universal como Norma, "uma situação não-espacial, mas que cria e recria espaços locais".

Como os grandes projetos de investimento de capital se implantam em espaços que são lugares, pode-se afirmar que esses estabelecem processos de conflitos entre o território da mineração resultante e as territorialidades desses lugares. Os processos de coabitação e hibridização, forçada ou espontânea, são contraditórios e marcados por relações de poder que podem subsistir como permanentes tensões ou desencadear conflitos abertos. Isso evidencia o que Pritchard (2011) denomina de conflitos no envirotechnical regime. Os componentes socioeconômicos, socioculturais e ecológicos locais podem estar apropriados e hibridizados no envirotechnical landsca- 
pe da mineração; ou podem estar justapostos; ou podem estar sobrepostos; porém, nos três casos, haverá impacto sobre os habitats, os hábitos e os coabitantes humanos e não-humanos territorialmente localizados.

A sobrecodificação promovida pelo Estado e a resultante dos grandes projetos (mineração em larga escala, hidrelétricas, pastagens extensas, monoculturas etc.) promovem uma homogeneização não apenas socioeconômica, mas também ecológica. Na verdade, é uma homogeneização biocultural (ROZZI, 2013), pois ocorre uma redução drástica da diversidade biológica e da diversidade cultural. Esses lugares constituem particularidades sem projetação para fora dos seus locais de origem e possuem pouca ou nenhuma capacidade de se expressar no envirotechnical regime. Essa fraqueza foi identificada pelo Ministério Público de Minas Gerais, quando criticou no PL 3.676/16, em tramitação na Assembleia Legislativa estadual, a falta da obrigação de se realizar audiências públicas em todas as comunidades atingidas pela implantação e funcionamento da atividade minerária.

Para examinar as contradições do envirotechnical regime envolvendo os atores sem projeção para fora dos seus lugares de origem, o conceito de ética biocultural (ROZZI, 2013) se apresenta como uma ferramenta analítica capaz de integrar os conceitos anteriormente propostos e, ao mesmo tempo, oferecer bases para uma abordagem interdisciplinar. O princípio ecológicofilosófico da ética biocultural considera a conservação de habitats locais e de hábitos de vida como cruciais para a existência, identidade, subjetividade e bem-estar dos coabitantes humanos e não-humanos. Nesse sentido, garantir a existência, independência e identidade dos habitats e o acesso a eles pelas comunidades de coabitantes é visto como um imperativo ético. Essa ferramenta funcionaria como uma chave que abriria as portas para inclusão dessas três esferas mencionadas (habitats, hábitos e coabitantes) no envirotechnical regime, isto é, um mecanismo de empowerment das comunidades territorialmente localizadas (assenhoramento pelos atingidos de suas próprias vidas e dos seus habitats) e, ao mesmo tempo, de dar voz aos outros seres, por meio dos movimentos socioambientais, dos ecologistas de toda linhagem, dos cientistas e do ministério público.

O desastre da Samarco/Vale/BHP é um campo de verificação da operacionalidade dos conceitos propostos. Como parte do projeto "Território da Mineração em Minas Gerais", financiado pela Fundação de Amparo à Pesquisa de Minas Gerais (FAPEMIG), se investigou a presença da Samarco Mineração S.A. na Internet, acompanhando sua trajetória desde a aquisição da mineradora pela Vale, assunto que concentrou a atenção do ano de 2000. Entre o período de 2001 e 2006, os assuntos se dividiram em duas abordagens: de um lado a expansão da empresa, sua "eficiência operacional" (lavras de custo baixo), o transporte por minerodutos e o aumento da capacidade portuária; por outro lado, está o discurso que apresenta a Samarco como empresa transparente e integrada com as comunidades onde atua, além de destacar os projetos ambientais e sociais mantidos pela empresa. Essa prática discursiva se repetira nos anos seguintes.

Merece atenção o artigo de Francisco Fernandes (2006, p. 94), publicado pelo site do Centro de Tecnologia Mineral (CETEM) do Ministério da Ciência, Tecnologia, Inovações e Comunicações (MCTIC), com o título "Responsabilidade socioambiental e trabalho infantil na mineração". Vinculado ao CETEM e com doutorado em Engenharia de Minas, pela USP, Fernandes (2006) exemplifica uma prática discursiva que eleva o mérito de determinado ator, ao distinguir duas situ- 
ações, nos quais a imagem positiva é contraposta a outra, que está associada no senso comum a estereótipos negativos, de forma a conseguir a validação do mérito proposto.

\begin{abstract}
Ainda, um caso, esse positivo aconteceu, em relação à compra de matéria-prima de um fornecedor, foi exemplar a atitude de um engenheiro da Samarco Mineração, quando ao visitar um fornecedor no oeste da Índia, teve a visão assustadora da precariedade das condições de trabalho, em que trabalhadores mineiros manipulavam ácidos sem qualquer proteção e a pele de seus braços estava despigmentada. O seu relatório convenceu o presidente da empresa a não negociar mais, até que anos depois, em 2003, a matriz dessa fornecedora, deu garantias de que as condições de segurança estavam sendo observadas.
\end{abstract}

Nos anos seguintes, até a véspera do desastre, a empresa se projetou ao responder uma pauta explicitamente neoliberal; resultados econômicos, redução de custos de produção, implantação de novas tecnologias e maximização dos lucros. No ano de 2011 ganharam repercussão os novos contratos com empresas da Ásia e Europa e o fato das exportações da Samarco terem ultrapassado as da Vale, fazendo da empresa a maior exportadora de Minas Gerais. Parte desse sucesso justifica o projeto de construção da quarta usina de pelotização e de um novo mineroduto. Como no período anterior, cresceu ainda mais a construção da imagem da Samarco como empresa protetora do meio ambiente e preocupada com a sociedade, particularmente com as comunidades vizinhas e de Mariana. A Samarco aparece como uma das melhores empresas para se trabalhar, porque investia no desenvolvimento dos empregados; beneficiava as comunidades vizinhas às suas plantas industriais; empegava mão-de-obra local; reajustava os salários e concedia vários benefícios. Essa imagem de empresa comprometida social e ambientalmente está no auge no ano que antecede o desastre, com várias inserções no próprio site, na página da Vale e em todos os demais meios midiáticos. Em 2014, a responsabilidade social e ambiental e a preocupação com a segurança garantiram à Samarco a quinta premiação, pela revista Veja, de melhor mineradora.

Em 2013 um conjunto de eventos envolvendo a Samarco foi repercutido positivamente na mídia, nos meios políticos e junto as entidades empresariais, confirmando que o padrão avaliativo era pautado pelo neoliberalismo. Entretanto, depois do 5 de novembro de 2015, a avaliação sobre o modo como a Samarco enfrentou a conjuntura de queda dos preços do minério de ferro passou de positiva para negativa. As ações da empresa, a partir de 2013 , são vistas hoje como a causa mais profunda do desastre. Na conjuntura de preços baixos, a Samarco priorizou o aumento da extração de minério, a introdução de tecnologias mais eficientes, a conclusão da quarta usina de pelotização; a construção do novo mineroduto; a diminuição dos custos de produção. Essas ações permitirão ampliar significativamente as exportações.

Confirma o que estamos argumentando o fato de que permaneceu ausente da mídia e não se encontra menção na Internet, o laudo técnico de 2013, encomendo pelo do Ministério Público de Minas Gerais, que alertava para os riscos de rompimento da barragem do Fundão, em Mariana. A multiplicação de referências na Internet e matérias na imprensa sobre esse laudo somente ocorreu depois do desastre.

Estudos anteriores apontavam a relação entre baixa dos preços e ocorrência de desastres no setor minerário. Davies e Martin (2009) demostram que o aumento dos preços no mercado internacional de minério, no período de 2005-2008, foi sem precedentes, mas a alta refletia tão somente a característica cíclica desse segmento, marcado por períodos de baixa, mais ou menos 
prolongados. Os dados reunidos pelos autores apontam o crescimento de rompimento de barragens nos períodos de baixa, quando as empresas iniciam uma corrida competitiva, na qual aumentam as margens de risco para garantir os níveis de lucratividade e de dividendos para os acionistas. Bowker \& Chambers $^{27}$ associam o aumento da ocorrência de rompimentos de barragens à introdução de "tecnologias modernas de mineração, que permitem a implantação de megaminas" com rochas de baixa concentrações (MANSUR et. al., 2016, p. 3). A Vale adotou essa estratégia na década de 2000, ao introduzir tecnologias potentes para assegurar maior pureza e valor agregado em minas de rochas de menor teor. O resultado foi o aumento significativo na quantidade de rejeitos e, consequentemente, a crescente pressão sobre os sistemas de barramento de contenção (SANTOS, 2016b, p. 126). Todos esses motivos e ações apontadas acima estão presentes no caso da Samarco, como aponta Mansur et al. (2016, p. 20-21).

O inquérito da Política Federal (IPL/SRPF) ressaltou que a Samarco tinha conhecimento da proximidade do ponto de saturação da barragem de Germano, pois isso consta do Estudo de Impacto Ambiental e seu respectivo Relatório de Impacto Ambiental (EIA-RIMA/2005). Os riscos eram maiores para o povoado de Bento Rodrigues, localizado a jusante da barragem (cerca de 3 km, em linha reta). A escolha da localização do córrego Fundão para a construção de um outro barramento não considerou o risco para Bento Rodrigues. Além de não considerar a localização como fator de risco, os engenheiros optaram por técnica construtiva de barramento que não se apresenta como a mais segura - alteamento a montante. ${ }^{28} \mathrm{O}$ EIA-RIMA/2005, por absurdo que possa parecer, afirma não existir comunidade vizinha à barragem de Fundão, mesmo registrando a presença do povoado a seis $\mathrm{km}$. O texto apresenta um cinismo não apenas do ponto de vista da ética e da justiça ambiental, mas também se usarmos critérios puramente técnicos que orientam a confecção dos EIA-RIMA e a atividade dos engenheiros. IPL/SRPF denuncia a intensão de esconder os moradores à jusante do empreendimento, por meio de artifícios de linguagem. Atitude que faz do desastre socioambiental um crime, se não pelo impacto sobre os fatores bióticos e socioeconômicos a jusante da barragem, que chegou ao mar, com certeza pela morte de 19 pessoas de Bento Rodrigues.

Com o foco nas comunidades vizinhas da planta industrial da Samarco, se buscou verificar se o complexo minerário com suas barragens era "invisível" aos olhos dos moradores de Bento Rodrigues, Mariana e outras localidades próximas. Na verdade, não era invisível, no sentido de a população saber da sua existência e, até mesmo, se sentir beneficiada pelos projetos sociais e ambientais que eram frutos da presença da empresa. Entretanto, os riscos associados a atividade minerária e as barragens eram invisíveis e isso era mantido assim. Em todos os anos pesquisados, anteriores ao desastre, não se nota notícia sobre falhas operacionais, pelo contrário, sempre eram exaltadas a eficiência e a "preocupação" com a segurança, sustentabilidade, meio ambiente e comunidades próximas. Por várias vezes foi eleita como referência nesses quesitos, tendo inclusive, no ano do desastre (2015) ganhado dois prêmios nesse sentido.

A partir do desastre, os componentes socioeconômicos, socioculturais, sociotécnicos, jurídico-políticos e de governança empresarial ligados ao envirotechnical system da mineração pas-

27 "The risk, public liability, \& economics of tailings storage facility failures". Disponível em file:///C:/Users/haruf.MILLENIUM/Downloads/Tailings+Failure+Risks+Chambers Bowker+2015 07 21.pdf. Acessado em 30 out. 2017.

${ }^{28} \mathrm{O}$ método de montante é de difícil controle em sua construção porque os alteamentos são realizados sobre materiais previamente depositados e sem estabilidade. 
saram a receber um outro enfoque. O desastre da Samarco não é uma exceção, mas faz parte dos custos humanos, sociais e ambientais associados à atividade minerária em todo o mundo, ao longo do tempo. Tais eventos compartilham causas semelhantes: manutenção deficiente das estruturas de drenagem, ausência de monitoramento contínuo e controle durante a construção e operação, alteamento das barragens sem adequados procedimentos de segurança, sobrecarga e falta de regulamentação sobre os critérios de projetos específicos. Como realizadores dos estudos, aplicadores das técnicas construtivas e executores das obras das barragens, são os engenheiros e a engenharia responsáveis diretos. ${ }^{29}$

Minas Gerais registrou seis ocorrências de rompimentos de barragens, nos últimos 15 anos (ALVES, 2017). Bowker e Chambers (2015, apud Milanez, 2016), ao analisar os rompimentos de barragens, ocorridos entre 1910 e 2010, identificaram mais de 30 eventos sérios e muito sérios no mundo, após 1990. Eles notaram que essa tendência é consequência das tecnologias modernas de mineração, que permitem a construção de minas cada vez maiores e a extração de minérios de reservas com concentrações cada vez menores. Como consequência da baixa concentração de minério na rocha, mais rejeitos são gerados no processo de beneficiamento e, ao mesmo tempo, maiores serão a estruturas de contenção. O desastre da Samarco/Vale/BHP se enquadra nesse padrão, que associamos à tendência dominante de desregulamentação que corresponde ao predomínio do neoliberalismo na década de 1990.

A grande concentração de atividade minerária no estado de Minas Gerais (Figura 03), como visto inicialmente, cria situações de vulnerabilidade para terceiros, em função da localização das minas e das barragens de contenção de rejeitos nos sítios mais elevados das bacias hidrográficas dos rios São Francisco, Doce e Grande, particularmente na Serra do Espinhaço (Quadrilátero Ferrífero). Em 2015, a Fundação Estadual do Meio Ambiente (FEAM, 2016) tinha no seu cadastro 730 barragens, 3,29\% a menos que em 2014 (754), com $442(60,5 \%)$ delas de mineração, 1,8\% menos que em 2014 (450). O período entre 2008 e 2014 foi marcado pela expansão das atividades econômicas e, consequentemente, por um crescimento de $24,6 \%$ do número de barragens (FEAM, 2015, p. 21). Esse crescimento e o perigo representado somente chamou a atenção da imprensa nos dias que se seguiram ao 5 de novembro de 2015, como no exemplo da manchete do jornal "O Tempo" (16/11/2015): "Minas Gerais recebeu, em média, 12 novas barragens de rejeitos de mineração por ano (uma por mês), entre 2008 e 2014, passando de 373 para 450 estruturas". ${ }^{30}$

\footnotetext{
${ }^{29}$ Por isso a importância do correto exercício das funções de engenheiro, dos princípios éticos e deveres profissionais. No Brasil a engenharia e os engenheiros seguem os princípios éticos e normas regulamentados pela Lei n. ${ }^{\circ} 5.194 / 66$ e pela resolução do Conselho Federal de Engenharia e Arquitetura (CONFEA, 2002) n. ${ }^{0} 1.002 / 2002$, onde estão descritos deveres como: "utilizar técnicas adequadas"; "assegurar os resultados propostos e a qualidade satisfatória nos serviços e produtos"; "observar a segurança nos seus procedimentos"; "prezar pela preservação e desenvolvimento do ser humano, de seu ambiente e de seus valores", "alertar seus clientes, empregadores e colaboradores dos riscos e responsabilidades relativos às orientações técnicas" e às possíveis consequências caso estas sejam descumpridas. Disponível em http://normativos.confea.org.br/ementas/visualiza.asp?idEmenta=542. Acessado em 30 out. 2017.

30 SUAREZ, Joana. "Armadilhas". Minas ganha 12 barragens de rejeitos de mineração por ano. O Tempo, Contagem, MG. Publicado em 16/11/15. Disponível em http://www.otempo.com.br/cidades/minas-ganha-12-barragens-de-rejeitosde-minera\%C3\%A7\%C3\%A30-por-ano-1.1170011 Acessado em 6 nov. 2017.
} 


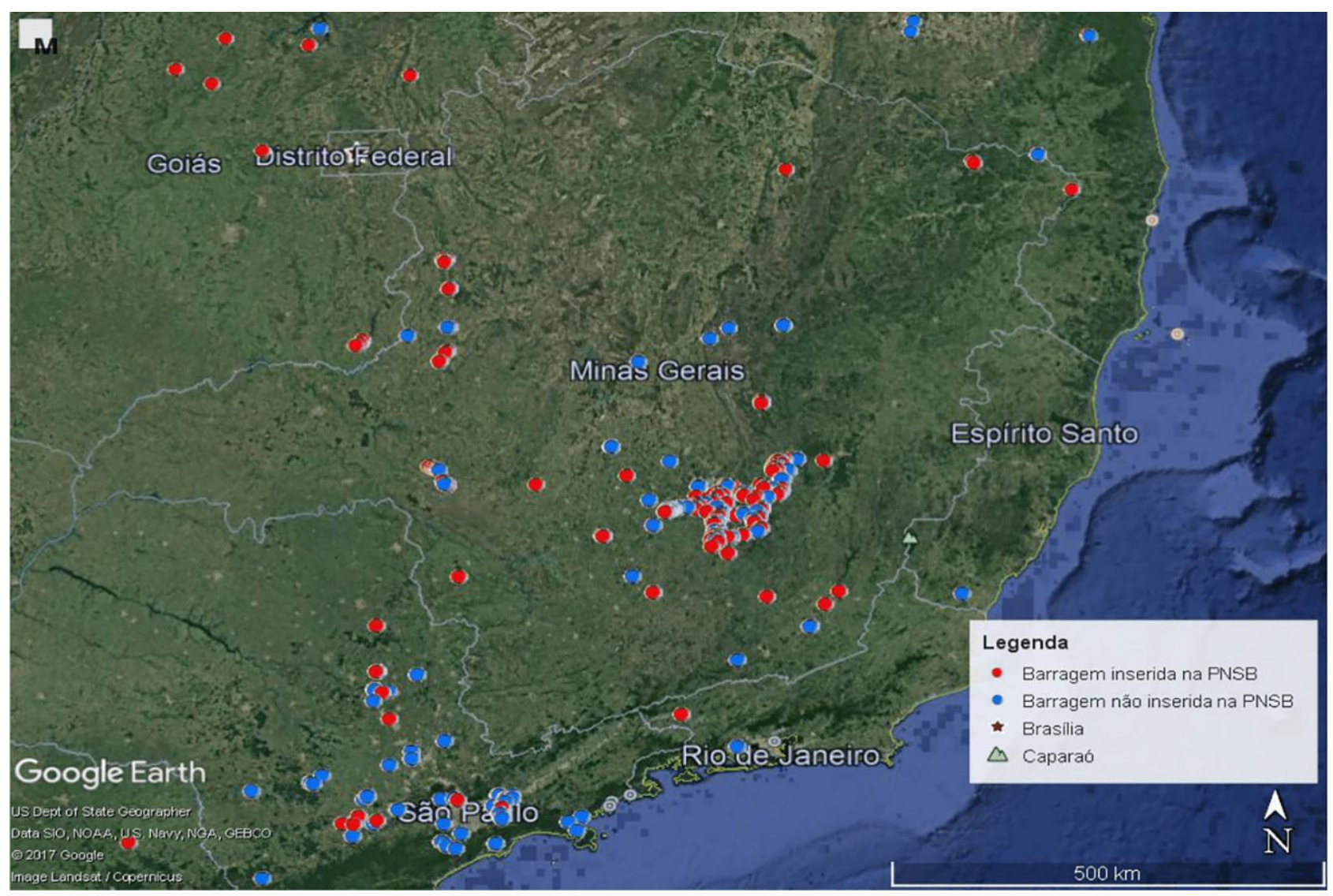

Figura 03: A concentração de atividade minerária no estado de Minas Gerais é identificada pelo grande número de barragens localizadas na região central, particularmente no denominado Quadrilátero Ferrífero, na Serra do Espinhaço, nos divisores de água das bacias dos rios São Francisco, Doce e Grande.

É necessário considerar que os impactos atingem todos coabitantes da bacia do rio Doce, porém não se pode olvidar que determinados territórios e territorialidades se encontravam e se encontram em situação de maior vulnerabilidade e incertezas frente ao desastre consumado e a aos riscos representados pelo envirotechnical system da mineração. São essas vozes, historicamente silenciadas, que se levantaram para se fazer ouvir, como na manifestação que reuniu agricultores, pescadores, movimentos sociais e ribeirinhos para ocupar a estrada de ferro da Vale S.A. na cidade de Governador Valadares, em 8 de novembro de 2017, com a ação que denominaram de "Revolução dos Peixes: se os homens não falam, os peixes falarão"; da mesma forma que o povo Krenak fechou a ferrovia no município de Resplendor (MG), por diversas vezes, desde o ato de $1^{\circ}$ de dezembro de 2015, realizado com apoio de outros povos, sobretudo Tupinikim e Guarani, que vivem no Espírito Santo.

\section{Conclusão}

Procuramos incorporar conceitos que funcionassem como ferramentas analíticas, mas evitamos usar os correlatos desses conceitos, ou seja, se utilizou território e territorialidade, mas se evitou nessa primeira reflexão trazer os conceitos de territorialização, desterritorialização e reterritorialização. Dessa forma os conceitos que utilizamos podem dar lugar a reflexões teóricas mais refina- 
das e, ao mesmo tempo, oferecer ainda ferramentas analíticas mais poderosas. Os conceitos utilizados podem ser assim listados: sistema territorial; território e territorialidade (RAFFESTIN, 1993; SACK, 1986); multiterritorialidade (HAESBAERT, 2007); território normado e território como norma (ANTAS JR., 2005); envirotechnical, envirotechnical landscape, envirotechnical system e envirotechnical regime (PRITCHARD, 2011); sobrecodificação (DELEUZE; GUATTARI, 2010); biocultural e ética biocultural (ROZZI, 2013).

Conhecer o envirotechnical system da mineração é importante para quem deseja se posicionar no debate e na construção de alternativas ao modelo atual. A mineração em grande escala é concentrada nas cabeceiras de grandes rios formadores da bacia hidrográfica e, consequentemente, os riscos potenciais para todas populações e habitats a jusante são significativos. O desastre-crime do rompimento da barragem de Fundão e outros crimes relacionados à atividade extrativista são continuamente denunciados pelo Ministério Público e organizações sociais e ambientais, a exemplo da International Articulation of People Affected by Vale (Articulação Internacional dos Atingidos pela Vale). Os desastres minerários, em todo mundo, atingem principalmente populações vulneráveis, sendo que em determinados casos configuram forma de racismo ambiental, caracterizada como violência sobre populações negras e mestiça, povos indígenas e comunidades tradicionais.

Para evitar os riscos de eventos semelhantes ao desastre da Samarco/Vale/BHP é importante rever as exigências do EIA-RIMA, aumentar o controle social externo e criar grupos técnicos independentes de fiscalização e acompanhamento, particularmente exigir que o CREA tenha poder de veto, que obrigue as partes negociarem as decisões técnicas, não permitindo que essas fiquem subordinadas a opções gerenciais das empresas, capazes de relativizarem ou negligenciarem os aspectos de segurança. As propostas de mudança do Código de Mineração devem ser outras, bem diferentes das que estão em discussão no parlamento brasileiro. Os estados devem adotar leis mais rígidas, incluindo propostas como as feitas pelo Ministério Público de Minas Gerais: licenciamento trifásico; audiências públicas em todas as comunidades atingidas; obrigação da caução (garantias financeiras prévias); o uso de tecnologias mais seguras e menos impactantes.

O desastre da Samarco/Vale/BHP alargou o envirotechnical regime da mineração, ao deixar claro que o risco é muito mais extenso e as ameaças muito mais abrangentes, podendo afetar diferentes dimensões: de natureza social (cidades, vilas, povoados e comunidades rurais ao longo das calhas dos rios); de natureza econômica (empreendimentos econômicos empresariais e diferentes atividades de subsistência); de natureza ecológica (parques, unidades de conservação, áreas de proteção permanentes, matas ciliares, habitats diversos e seus coabitantes); de natureza cultural (patrimônio histórico e arqueológico, paisagens naturais e bens materiais e imateriais que refletem os modos de vida, subjetividades e hábitos diversos); de natureza financeira (gastos públicos ou privados para mitigação de perdas; indenizações diversas; e restauração/recuperação de imóveis, serviços urbanos, infraestruturas, paisagens, solos, equipamentos, entre outros); de natureza subjetiva (impossibilidade de mitigação, restauração ou recuperação decorrente de morte, dano irreparável ou remoção dos locais originários).

Como existem os riscos, é preciso considerar as medidas de redução dos danos: implantação de medidas preventivas, simulação e treinamento da população, instalação de sistemas de alerta precoce, fiscalização periódica (garantindo-se pessoa qualificada e recursos para suas ati- 
vidades) e adoção de centros de pesquisa, inovação e desenvolvimento capazes de produzir avanços técnicos e estruturais que assegurem estruturas mais eficientes e seguranças.

Os conceitos aqui propostos possibilitam alargar a compreensão do território da mineração e, ao mesmo tempo, incluir os pluralismos e heterogeneidades socioespaciais que compõem os diferentes habitats com seus diversos coabitantes e respectivos hábitos. Dessa forma, emerge o cerne do fenômeno criado pela presença do complexo minerado-metalúrgico: as contradições como relacionalidades marcadas pelo poder. Assim, é possível tratar com maior racionalidade e ética os riscos e, ao mesmo tempo, lidar subjetivamente com as incertezas, inclusive entendendo melhor as populações (humanas e não-humanas), seus habitas e hábitos. Finalmente, ao assumir uma ética biocultural deixamos de lado a falsa generalização de que o "homem" está destruindo a natureza, para assumir o compromisso de apontar claramente os atores privados e públicos efetivamente responsáveis e, portanto, fazer os enfrentamentos no jogo relacional do poder.

Submetido em 1 de dezembro de 2017. 
Referências

ALVES, H.R. O Rompimento de Barragens no Brasil e no Mundo: desastres mistos ou tecnológicos? Dom Total, Belo Horizonte, p. 1-5, 18 de dez. de 2015. Disponível em https://pt.scribd.com/document/310683914/Artigo-HRA\#. Acessado em 17 out. 2017.

ANTAS JR., R.M. Território e Regulação. São Paulo, Associação Editorial Humanas: FAPESP, 2005.

ARRUDA, G. Bacias hidrográficas, história ambiental e temporalidades. Revista de História Regional, v. 20, p. 209-231, 2015.

CAMPOS, P.H.P. A ditadura dos empreiteiros: as empresas nacionais de construção pesada suas formas associativas e o Estado ditatorial brasileiro, 1964-1985. (Tese de doutorado em História). Niterói: Universidade Federal Fluminense, 2012.

COELHO, A.L.N. Bacia hidrográfica do rio doce (MG/ES): uma análise socioambiental integrada. Geografares, n. 7, p. 131-146, 2017.

DAVIES, M.; MARTIN, T. Mining Market Cycles and Tailinam Incidents. Ings $D$ : 13th International Conference on Tailings and Mine Waste, Banff, AB, 2009. Disponível em http://www. Infomine.com/publications/docs/Davies2009.pdf. Acessado em 20 nov. 2017.

DELEUZE, G.; GUATTARI, F. O anti-Édipo: capitalismo e esquizofrenia. São Paulo: Ed. 34, 2010.

DNPM - DEPARTAMENTO NACIONAL DE PRODUÇÃO MINERAL. Cadastro nacional de barragens de mineração. 2016a. Disponível em http://www.dnpm.gov.br/assuntos/barragens/cadastro-nacional-de-barragens-de-mineracao. Acessado em 17 out. 2017.

DNPM - DEPARTAMENTO NACIONAL DE PRODUÇÃO MINERAL. Anuário mineral brasileiro de 2016. Brasília: DNPM, 2016b. Disponível em http://www.dnpm.gov.br/dnpm/publicacoes/serie-estatisticas-e-economia-mineral/anuariomineral/anuario-mineral-brasileiro/anuario-mineral-brasileiro-2016-metalicos. Acessado em 17 de out. 2017.

ESPINDOLA, H.S. O Centauro Maquiavélico. Ideologia da Revista Cultura Política (19411945). (Dissertação de Mestrado). Brasília-DF: UnB, 1988.

ESPINDOLA, H.S. O rio Doce e a emancipação da economia nacional (Brasil). Historia Ambiental Latinoamericana y Caribeña (HALAC), v. 5, p. 10-27, 2015.

GODOY, M.M.; BARBOSA, D.H.D.; BARBOSA, L.S. Da arte de conhecer as doenças: o Diagnóstico da Economia Mineira de 1968 e o planejamento do desenvolvimento de Minas Gerais. Nova Economia v.20, n.2, p. 343-388, 2010.

FEAM. Inventário de barragem do Estado de Minas Gerais. 2015. Belo Horizonte: Fundação Estadual do Meio Ambiente-FEAM, 2016. Disponível em http://www.feam.br/images/stories/2016/RESIDUOS MINERA\%C3\%87\%C3\%830/Invent\% C3\%A1rio de Barragens 2015 Final V01.pdf. Acessado em 20 nov. 2017. 
FEAM. Inventário de barragem do Estado de Minas Gerais. 2014. Belo Horizonte: Fundação Estadual do Meio Ambiente-FEAM, 2015. Disponível em http://www.feam.br/images/stories/2015/DECLARACOES AMBIENTAIS/GESTAO DE BAR RAGENS/correo inventrio\%20de\%20barragens 2014 final.pdf. Acessado em 20 nov. 2017.

FERNANDES, C.L.L. Economia e planejamento em Minas Gerais nos anos de 1960 e 1970. Revista Gestão \& Tecnologia, v. 8, n. 1, p. 11-39, 2007.

FERNANDES, F.R.C. Responsabilidade socioambiental e trabalho infantil na mineração. In: Zuleica Carmen Catilhos; Maria Helena Machado Rocha Lima; Nuria Fernández Castro (Org.), Gênero e trabalho infantil na pequena mineração. Rio de Janeiro: CETEM, 2006, p. 94108.

FISCHER, G. Das Staatsunternehmen als Expertenarena. Die Anfangsjahre der Companhia Vale do Rio Doce. In: Stefan Rinke and Delia González de Reufels (Eds), Expert Knowledge in Latin American History. Local, Transnational, and Global Perspectives. Stuttgart: Heinz, 2014, p. 109-138.

GONÇALVES R.; PINTO, R.G.; WANDERLEY, L.J. Conflitos ambientais e pilhagem dos territórios na bacia do rio Doce. In.: ZONTA Marcio; TROCATE Charles (Orgs.). Antes Fosse Mais Leve A Carga: Reflexões sobre o desastre da Samarco/Vale/BHP Billiton. Marabá: Editorial iGuana, 2016, p. 139-181.

HAESBAERT, R. O mito da desterritorialização: do "fim dos territórios" à multiterritorialidade. 3a ed. Rio de Janeiro: Bertrand Brasil, 2007.

MAGNO, L. Ordenamento territorial da mineração no Brasil e conflitos ambientais. Geografias ARTIGOS CIENTíFICOS, Belo horizonte, v. 11, n. 1, p. 84-107, 2015.

MANSUR, M.S. et al. Antes fosse mais leve a carga: introdução aos argumentos e recomendações referente ao desastre da Samarco/Vale/BHP Billiton. In: ZONTA Marcio; TROCATE Charles (Orgs.). Antes Fosse Mais Leve A Carga: Reflexões sobre o desastre da Samarco/Vale/BHP Billiton. Marabá: Editorial iGuana, 2016, pp. 17-49.

MINISTÉRIO PÚBLICO FEDERAL. Força Tarefa Rio Doce. IPL n. ${ }^{0}$ 1843/2015 SRPF/MG; Autos n. ${ }^{0}$ 38.65.2016.4.01.3822 (Busca e apreensão); Autos n. ${ }^{0}$ 3078-89.2015.4.01.3822 (Medida Cautelar); IPL Polícia Civil - MG 1271-34-2016.4.01.3822; IPL Polícia Civil - MG 125024.2016.4.01.3822; Procedimento Investigatório Criminal (PIC) - MPF n. ${ }^{0}$ 1.22.000.003490/2015-78; Procedimento Investigatório Criminal (PIC) MPF n. ${ }^{\circ}$ 1.22.000.000003/2016-04.

NORA, P. O retorno do fato. In: NORA \& LÊ GOFF (Orgs), Novos Problemas. Rio de Janeiro: Francisco Alves, 1976.

PIMENTA, D.J. O minério de ferro na economia nacional. (O vale do rio Doce). Rio de janeiro, s/ed, 1950.

PRITCHARD, S.B. Confluence: the nature of technology and the remaking of the Rhône. Cambridge: Harvard University, 2011. 
ROZZI, R. Biocultural Ethics: From Biocultural Homogenization Toward Biocultural Conservationo. In.: R. Rozzi et al. (eds.), Linking Ecology and Ethics for a Changing World: Values, 9 Philosophy, and Action, Ecology and Ethics. Dordrecht: Springer, 2013.

SANTOS, J.R. Evitar o impensável: a destruição irremediável do quadro de vida. Uma análise a partir do Projeto de Mina de Ouro da Boa Fé. In.: GUIMARÃES, P.E.; CEBADA, J.D. P. (Ed.). Conflitos Ambientais na Indústria Mineira e Metalúrgica: o passado e o presente. Évora: CICP - Centro de Investigação em Ciência Política, Portugal; Rio de Janeiro: CETEM - Centro de Tecnologia Mineral, Brasil, 2016a, p. 185-212.

SANTOS, R.S. WANDERLEY, L.J. Dependência de barragem, alternativas tecnológicas e a inação do estado: repercussões sobre o monitoramento de barragens e o licenciamento do Fundão. In.: ZONTA Marcio; TROCATE Charles (Orgs.). Antes Fosse Mais Leve a Carga: Reflexões sobre o desastre da Samarco/Vale/BHP Billiton. Marabá: Editorial iGuana, 2016b, p. 87-137.

SANTOS, M. A Natureza do Espaço. Técnica e tempo, razão e emoção. Editora Hucitec, São Paulo, 1996.

SILVA, M.Z. A Vale do Rio Doce na estratégia do desenvolvimentismo brasileiro. Vitória: EDUFES, 2004.

SIMONINI, Y. Portos para o Nordeste: ideias, transformações e conflitos nas províncias do norte do Brasil (Fortaleza, Natal e Parahyba, 1869 - 1934). Tese (Doutorado em História). Belo Horizonte: Universidade Federal de Minas Gerais, 2017. 461p.

TRINER, G.D. Mining and the State in Brazilian Development. London: Pickering \& Chatto, 2011.

VILARINO, M.T.B. Da lata d'agua ao SESP: tensões e constrangimentos de um processo civilizador no Sertão do Rio Doce (1942-1960). (Tese de Doutorado). Belo Horizonte: Universidade Federal de Minas Gerais, 2015.

ZONTA M.; TROCATE, C. (Orgs.). Antes Fosse Mais Leve a Carga: reflexões sobre o desastre da Samarco/ Vale I BHP Billiton. Marabá, PA: Editorial Iguana, 2016. 